\title{
PARRESÍA E CINISMO COMO MODO DE VIDA: FOUCAULT E A AÇÃO POLÍTICA
}

\author{
PARRHESIA AND CYNICISM AS WAY OF LIFE: FOUCAULT AND POLITICAL ACTION.
}

\author{
Sergio Fernando M. Corrêa*
}

\section{RESUMO}

Este artigo busca analisar as relações e tensões entre parresía política e parresía cínica que Michel Foucault apresenta nos últimos cursos no Collège de France, a saber, Le gouvernement de soi et des autres e La courage de la vérité de 1983 e 1984. Partimos de duas noções de política em Foucault: política como estratégia de governamentalidade e política como resistência e insurreição. O texto se empenha em problematizar as formas institucionais de participação política e traz como hipótese principal que a forma de vida cínica pode oferecer um conteúdo importante para a ação política. A forma de vida cínica passa pela valorização da corporeidade, pela vida simples e desapegada e pelo distanciamento dos costumes culturais e políticos. A partir dessa descrição do cinismo pleiteamos uma ampliação da comunidade moral e política.

PALAVRAS-CHAVE: Parresía. Cinismo, Democracia. Ação Política. Modo de Vida.

\section{ABSTRACT}

This paper seeks to analyze the relations and tensions between political parrhesia and cynical parrhesia that Michel Foucault presents in his last years at the Collège de France, namely, Le gouvernement de soi et des autres de 1883 and La courage de la vérité de 1984 . We start from two notions of politics in Foucault: politics as strategy of governmentality and politics as resistance and insurrection. The text tries to problematize the institutional forms of political participation and he brings as the main hypothesis that the cynical way of life can offer important content for political action. The cynical way of life goes through the valuation of corporeality, the simple and detached life and the distancing of cultural and political mores. From this description of cynicism, we plead for an expansion of the moral and political community.

KEYWORDS: Parrhesia. Cynicism. Democracy. Political Action. Way of life.

\section{INTRODUÇÃO ${ }^{1}$}

É razoável aceitarmos que os grandes dilemas políticos da antiguidade clássica se tornem atuais, ou melhor, que eles cheguem até o nosso presente histórico sem uma resolução definitiva uma vez que em uma época, como a nossa, muito se discute sobre o tipo de

\footnotetext{
* Mestre em filosofia pela Universidade Federal de Pelotas - UFPel, Doutor em Filosofia pela Universidade do Vale do Rio dos Sinos - UNISINOS. Professor do Instituto Federal Catarinense, Campus Videira-SC. E-mail: fer.ser29@gmail.com.

${ }^{1} \mathrm{O}$ artigo representa uma das possíveis abordagens da minha pesquisa nível de doutorado defendido na UNISINOS em abril de 2019 e também do projeto de pesquisa "Democracia, Educação e Parresía" em andamento no Instituto Federal Catarinense, Campus Videira-SC. Contou-se também com o apoio do Fundo de Apoio à Manutenção e ao Desenvolvimento da Educação Superior - FUMDES do Estado de Santa Catarina.
} 
democracia que queremos consolidar. Para nós ainda não é clara qual a melhor forma de distribuir e acessar o poder pois até então não é possível mensurar qual o grau de autonomia do cidadão no momento que exerce sua capacidade de decisão. Todas essas questões passam pelo elemento da discursividade que não é neutra e é mitigada de intenções.

Em outras palavras, este texto se depara com um paradoxo, posto que a democracia é a organização política que melhor favorece a existência de discursos livres e verdadeiros e ao mesmo tempo os coloca em perigo, como descreve Michel Foucault (2010, p. 170): "Não há democracia sem discurso verdadeiro, mas a democracia ameaça a própria existência do discurso verdadeiro". Desse modo, este breve artigo quer se aproximar de um problema formativo-epistêmico que precisa ser abordado e que é indispensável à qualificação da ação política. Com base nesse problema o trabalho de pesquisa se deterá no Cinismo e na forma de vida cínica, no esforço de buscar o que resta de conteúdo ético-político neste modo de vida e que pode aperfeiçoar o presente histórico da política.

\section{NOTAS HISTÓRICO-MITOLÓGICAS SOBRE A PARRESÍA POLÍTICA}

Poderíamos percorrer, junto com Foucault, uma trajetória histórico-genealógica da parresía que se inicia com o que é possível chamar de momento euripidiano da parresía ${ }^{2}$. Em linhas gerais, na fase trágico-mitológica é admissível constatar uma tensão entre a noção de política em Foucault como arte de governar e a noção de política como forma de resistência e enfrentamento ao poder. As personagens trágicas de Eurípedes - Íon e sua mãe Creusa apresentam esse embate, quando o primeiro quer ter o direito e o privilégio de participar da vida política ateniense, e a segunda precisa resistir e enfrentar o poder de Apolo para instituir a verdade histórica que fundaria a democracia. O fato é que a parresía serviu como forma de acesso e fruição de um direito político para Íon e como forma de resistência aos exageros do poder por sua mãe Creusa.

No campo histórico da constituição da democracia, Michel Foucault apresenta duas personagens importantes: Sólon e Péricles. O filósofo francês usa os textos de Diógenes de Laércio para apresentar Sólon como aquele que também sintetiza em si o privilégio político e resistência ao poder, pois ele pôde tomar a palavra na assembleia democrática e ao mesmo

\footnotetext{
${ }^{2}$ Já propomos esta análise no texto Cinismo e Parresía - Estética da Existência, Resistência e Revolução que foi comunicado e publicado nos anais do VII Colóquio Cátedra Unesco-Unisinos "Direitos Humanos e Violência, Governo e Governança, disponível em: http://repositorio.unisinos.br//ihu/V_CI_IHU.html.
} 
tempo, por suas vestes de guerra, demonstrar publicamente sua militância parresiasta. Péricles, por seu turno, aglutinou em sua prática virtudes ético-políticas de primeira grandeza, segundo Foucault. A partir de Tucídides, o filósofo francês pode apresentar a diferenciação ética do ateniense e sua coragem de enfrentar os desvios da sua comunidade política. Não teve somente capacidades epistêmicas para diagnosticar e verbalizar os desvios morais de sua coletividade política, mas teve a coragem ética de denunciar erros, mesmo correndo o risco do banimento e da morte. Este momento histórico representa, para Foucault, o ápice democrático na antiguidade.

Posteriormente a esses momentos míticos e históricos, Michel Foucault se dedica então a analisar a fase socrático-platônica da parresía, a qual representa um deslocamento da parresía do âmbito da política para o âmbito de uma prática filosófica de vida. As razões deste deslocamento não são em função de uma transmutação da noção da parresía, mas pelas transformações das condições políticas, da diminuição das estruturas formais da democracia que restringiu e muito a concepção de uma parresía política. Nesse caso, a parresía será menos política e mais filosófica, como está dito por Foucault (2010, p. 309):

\begin{abstract}
O parresiasta é agora alguém diferente, é um outro perfil, é um outro personagem. Já não é simplesmente, já não é somente, já é exatamente esse cidadão entre outros ou um pouco à frente dos outros. É um cidadão, vocês se lembram - vimos isso no caso de Sócrates -, claro que como os outros, que fala como os outros, que fala a linguagem de todo o mundo mas que se mantém, de certo modo, apartado dos outros. Essa substituição, ou antes, essa duplicação do parresiasta político, que é um cidadão à frente dos outros, pelo filósofo, que é um cidadão como os outros, que fala a linguagem de todo o mundo, mas apartado dos outros, isso me parece ser um outro aspecto dessa mesma transformação que procurei apreender.
\end{abstract}

Este outro modo de ser da parresía - filosófico - dada sua relação com a política sem ser da ordem da politeía adquire uma importância ímpar para o que buscamos com este artigo, por oferecer um conteúdo ético-político à própria filosofia. $\mathrm{O}$ filósofo parresiasta, diferente do cidadão clássico, terá outra forma de se relacionar com o poder, de enfrentar os processos de governamentalidade, de aventurar-se no jogo da verdade em relação ao governo e às relações de poder. O tema da vida filosófica que se relaciona de modo diferente com a política bem mais que um direito, bem mais que um privilégio, é um modo de existir que implica renunciar a certas coisas e menos acumular. As exigências de uma vida filosófica demandam o engajamento com certa doutrina formativa, o cultivo de aptidões físicas, uma forma de se relacionar com a propriedade e com os objetos materiais. Quando Foucault está refletindo com seus ouvintes sobre o conteúdo da vida filosófica em 1983, assinala: 
A vida filosófica é uma manifestação da verdade. Ela é um testemunho pelo tipo de existência que se leva, pelo conjunto de opções que se faz, pelas coisas a que você renuncia, pelas que aceita, pela maneira como você se veste, pela maneira como fala, etc., a vida filosófica deve ser, de ponta a ponta, a manifestação dessa verdade. (FOUCAULT, 2010, p. 311).

\section{NOTAS SOBRE UMA FILOSOFIA COMO FORMA DE VIDA: A PARRESÍA CÍNICA}

O estilo de vida filosófico descrito na passagem acima que retorna à antiguidade clássica pode ser remetido à pessoa de Sócrates e às várias escolas filosóficas de vida que o sucederam em especial ao Cinismo. O estilo de vida cultivado pelo filósofo ateniense não considerava importante saber bem argumentar perante a assembleia, mas analisar minuciosamente a maneira como se vivia ${ }^{3}$. O grande dilema que se iniciou com Sócrates e foi experimentado nas escolas filosóficas de vida não foi a pergunta: "quais os limites e possibilidades do entendimento humano na construção do conhecimento seguro e verdadeiro?", mas o dilema era: "de que modo melhor cultivar a si mesmo para construir uma forma de vida plenamente realizada?" Evidente que um dilema moral como este implica cultivar virtudes epistêmicas, já que esse tipo de questionamento conduz o indivíduo a fazer opções, renúncias e aceitar certas condições de existir, do mesmo modo que a forma de vida filosófica não pode dispensar a atividade técnica, pois demanda certa forma de falar, de fazer as coisas. Práticas ascéticas estão imbricadas com esta Episteme e essa Technê, pois a forma de vida, como bem disse Foucault, é o testemunho da forma de vida que se leva que remete à verdade que é uma verdade de si mesmo, uma Askesis ${ }^{4}$. Há autores que veem nesse conceito, um vínculo profícuo e uma continuação do cinismo nos primeiros séculos do cristianismo, como na passagem:

O campo comum compartilhado por cínicos e cristãos era, presumivelmente, a prática de um modo de vida ascético, mas o fim do "ascetismo" (askésis) cínico - a

\footnotetext{
${ }^{3}$ Pierre Hadot, por exemplo, que vê na filosofia de Platão uma continuidade do socratismo e do pitagorismo afirma que não havia uma intenção política pura na educação dos jovens que frequentavam a Academia, como era na atuação pedagógica dos sofistas, mas o processo formativo era direcionado para a formação de si: "Les sophistes avaient prétendu former les jeunes gens à la vie politique, Platon veut le faire en les dotant d'un savoir bien supérieur à celui que les sophistes pouvaient leur fournir, d'un savoir qui, d'une part, sera fondé sur une méthode rationnelle rigoureuse, et qui, d'autre part, selon la conception socratique, será inséparable de l'amour du bien et de la transformation intérieure de l'homme (HADOT, 1995, p. 96-97).

${ }^{4}$ Pierre Hadot registra que o exercício da dialética no âmbito da Academia não era puramente direcionado para a estimulação do raciocínio lógico, mas era um exercício espiritual em vista de uma formação de si mesmo: "C'est pourquoi la dialectique platonicienne n'est pas um exercice purement logique. Elle est plutôt un exercice spirituel qui exige des interlocuteurs une ascèse, une transformation d'eux-mêmes” (HADOT, 1995, p. 102).
} 
felicidade - é inequivocamente imanente e secular [...] No entanto, a semelhança ostensiva da virtude cínica com a pobreza - em particular a adoção da pobreza e de algum tipo de ascetismo - provoca inevitavelmente a admiração de muitos cristãos. (GOULET-CAZÉ; BRANHAM, 2007, p. 30)

Foucault dirá, a partir de Epicteto e sua obra Conversações, que o cínico vive à luz do dia livre e sem nada a temer porque "ele é, em sua vida, a verdade no estado manifesto" (FOUCAULT, 2010b, p. 315). Sabe-se que a filosofia antiga e as suas escolas filosóficas criaram e desenvolveram grandemente diversas ciências como a física, a lógica, a metafísica, a ética etc. Qual o sentido desses conhecimentos quando se tem a filosofia como uma forma de vida? Essas ciências representavam muito mais uma cosmologia existencial e uma experiência mística com o cosmos do que um aparato explicativo da ordem do mundo. Nesse sentido, tais conhecimentos foram desenvolvidos não em função de uma verdade enquanto correspondência entre os postulados de um sujeito do conhecimento e os objetos a serem conhecidos. A razão da criação de conceitos e da analítica conceitual que caracterizava a atividade filosófica clássica se dava em função da implementação de uma forma de vida que, a exemplo do cínico, seria a verdade em seu estado manifesto.

Outro autor a exaltar o significado das ciências particulares para Sócrates e os Cínicos é Luis Navia, que sustenta que uma das proposições do cinismo de Diógenes é de que o exercício do pensamento para conhecer algo se justifica em função de conferir sentido à existência humana e indicar possibilidades de melhor significar e re-significar o que se é: "Para Diógenes não menos que para Sócrates, o mundo começa e acaba na presença do ser humano. Ciência, Metafísica e toda sorte de atividade intelectual que transcendesse a existência humana não tinha, nesse sentido, nenhuma significação para ele" (NAVIA, 2009, p. 160). A filosofia não servia só para a constituição de uma forma de vida singular, característica de um ethos individual, mas era acompanhada de uma exigência política que era a proposição de uma cidade (politeía) ideal.

O professor Castor Ruiz, coordenador da Cátedra Unesco-Unisinos de Direitos Humanos, publicou uma série de artigos com a temática da filosofia como forma de vida nos Cadernos IHU On-line. No primeiro deles, o pesquisador descreve o que significava toda a atividade filosófica na antiguidade e se faz importante para termos uma compreensão mais significativa do fazer filosófico dos antigos. A passagem:

$\mathrm{O}$ ingente aparato conceitual das diversas escolas filosóficas tinha por objetivo implementar uma forma-de-vida. O desenvolvimento argumentativo da ontologia, da física, da cosmologia, da lógica, entre outras, só se entendia como saberes auxiliares 
da forma de vida. Por isso, todas elas enfatizavam a constituição do ethos como objetivo da filosofia e a criação da polis como uma forma coletiva de vida (RUIZ, 2015, p. 11).

Em primeiro lugar, o cínico é aquele que manifesta uma verdade corpórea, pois não procura esconder que, enquanto corporeidade, é um ser de desejos e de necessidades. Por isso o modo de viver do cínico é radicalmente diferente daquele modo de vida projetado pelas escolas de vida alinhadas com o platonismo que concebiam a corporeidade como uma fonte de erro, engano e de concupiscência da alma ${ }^{5}$. Nesse sentido, a sua forma de vida não busca ocultar esses desejos e necessidades de si mesmo e dos outros, como se houvesse uma separação entre vida pública e vida privada. Contudo, tal forma de compreender-se a si mesmo não implica bestialidade como se a fórmula "viver conforme a natureza" acarretasse certa irracionalidade. Por isso mesmo a ascese (áskesis) terá importante papel no cinismo não como mortificação do corpo ou como instrumento para negar por si mesmo o prazer. Luis Navia escreve sobre o tema da áskesis em Diógenes, o Cínico: "Por meio da disciplina, expressa em sua linguagem como áskesis, donde derivamos a palavra ascese, purificamos a mente de confusões e obscurecimentos, e o corpo, de substâncias nocivas hábitos antinaturais, logrando o fortalecimento da vontade" (NAVIA, 2009, p. 173). Nesse sentido, o cínico é transparência pura e nada pode ocultar do seu ser, pois se o fizer deixará manchado o seu modo de vida exatamente por ocultar algo da verdade de si.

Em segundo lugar, o cínico é uma consciência discursiva que não distingue hierarquias, status quo, o perigo e o saber-poder do interlocutor e a quem se dirige diz o que precisa ser dito. $\mathrm{O}$ ato de fala cínico, sua discursividade não atende aos interesses da retórica e nem se origina de uma diferenciação ética, como se o cínico fosse o mais indicado dos cidadãos convocados a falar e que, por suas habilidades e status, pudesse conduzir os demais a acatar a sua opinião. Por exemplo no artigo Desfigurar a moeda: a retórica de Diógenes e a invenção do cinismo, cujo objetivo é apresentar e defender a existência de uma retórica cínica, o autor brilhantemente defende que bíos e logos estão ligados pela parresía como forma de vida, e que essa é a condição de possibilidade de sustentar a existência de uma retórica genuinamente cínica. Em certa altura da discussão o autor escreve: "O tropo mais importante, tanto ideologicamente como retoricamente é o do corpo de Diógenes, que o põe

\footnotetext{
${ }^{5}$ Novamente a contribuição de Hadot é fundamental para uma compreensão adequada do que representou o cinismo no âmbito das escolas helenísticas de filosofia e também em relação ao modo de viver das pessoas em geral: "Le mode de vie cynique s'oppose d'une manière spectaculaire non seulement à celui des nonphilosophes, mais même à celui des autres philosophes" (HADOT, 1995, p. 170).
} 
continuamente em conflito com a sociedade [...] o corpo é uma fonte de autoridade do cínico, sua justificativa para exercitar a parrhésia” (BRANHAM, 2007, p. 115).

$\mathrm{O}$ ato corajoso de dizer a verdade do cínico não contém um designo político por si mesmo por se dirigir ao todo e não acontecer no âmbito de uma assembleia política, mas onde ele estiver. Trata-se de um enunciado que não distingue costumes sociais, normatividades políticas, perigos iminentes e respeito às hierarquias. Se for necessário ao cínico falar a verdade sobre uma prática cultural ou sobre os vícios da comunidade política e mesmo acerca dos exageros de um governante, ele falará sem temor ${ }^{6}$. Portanto, há um conteúdo éticopolítico na sua discursividade que beira uma democracia radical pela extrema igualdade donde parte sua visão de mundo, e é a partir de onde o seu ato de fala parresiasta é constituído:

Para dizer a verdade, o cínico está disposto a se dirigir inclusive aos poderosos, inclusive àqueles que são temíveis, sem que considere, de seu lado, que seja um perigo, para ele desastroso, perder a vida se seu dizer-a-verdade irritar aqueles a quem ele se dirigiu. (FOUCAULT, 2010, p. 315).

$\mathrm{O}$ ato corajoso de fala do cínico não pertence aos direitos políticos do cidadão e se mostra distante e exterior aos valores vigentes na ordem política. O cínico não dirá o que deve ser feito na arte de governar os outros e como se deve proceder no governo de si mesmo. $\mathrm{O}$ modo de vida cínico (sua filosofia) se caracteriza por estar frente a frente com a política, frente a frente com os costumes morais e nunca ficar recluso a esta ou aquela tendência política, a um ou outro valor moral vigente. Por essa razão o cínico tem a coragem da verdade, própria da parresía, que sem estar apegada ao status, às posses e aos valores que sustentam a moralidade dos costumes, será, como diz Foucault, com apoio dos textos de Epicteto, um batedor à frente da humanidade que aponta o que oferece riscos e vantagens aos seres humanos:

É para isso que o cínico, enviado como batedor, não poderá ter nem abrigo, nem lar, nem mesmo pátria. Ele é o homem da errância, é o homem do galope à frente da humanidade. E depois dessa errância, depois desse galope à frente da humanidade, depois de ter bem observado e consumado sua tarefa, o cínico deve voltar. Ele voltará para anunciar a verdade, anunciar as coisas verdadeiras sem deixar se paralisar pelo medo. Temos aqui a própria definição da parresía como exercício do

\footnotetext{
${ }^{6}$ Hadot, assim como Foucault, identifica nesse modode ser discursivo do cinismo a parresía: "Il ne craint pas les puissants et s'exprime en tous lieux avec une provocante liberté de parole (parrhesia)"(HADOT, 1995, p. 171).
} 
dizer-a-verdade que é anunciado aos homens sem nunca se deixar impressionar pelo medo. (FOUCAULT, 2011, p. 146).

Com esta passagem Michel Foucault insere, em 29 de fevereiro de 1984, definitivamente os cínicos no âmbito dos cursos do Collège de France para não mais cessar sua reflexão sobre o movimento filosófico antigo. O texto remete ao aspecto público do modo de vida cínico que não era protegido por um local privado como era a Academia, o Liceu ou a proteção da Stoa. Se o cínico é sem lar e até mesmo sem pátria, é salutar que compreendamos o movimento cínico antigo como um evento singular na história da filosofia cuja maneira de atuar era totalmente diferente do que até então se concebia como escola filosófica. As escolas de pensamento antigo sempre remetem a líderes, a textos e a um corpo de doutrinas e também a um lugar específico, porém a passagem acima com a qual Foucault apresenta o cinismo quebra essa concepção ${ }^{7}$. Contudo, a mesma passagem permite intuir algum conteúdo político que não está em um tratado de política como são, por exemplo, $A$ República de Platão e $A$ Política de Aristóteles. A referência do conteúdo político é a ação mesma do filósofo cínico, uma vez que não há doutrina ou texto em que estejam registrados os princípios e fundamentos de uma filosofia política cínica. O cínico está à frente da humanidade e sem nada de próprio cumpre uma tarefa que aos nossos olhos é eminentemente política, pois como a personagem que se livra da Caverna platônica, o sábio cínico também tem o dever de voltar e alertar os demais membros sobre o que é o real da vida cultural e política.

\section{O CONTEÚDO POLÍTICO DA FORMA DE VIDA CÍNICA}

A tarefa (política) do cínico é o anúncio corajoso da verdade, diz Foucault. Porém, a questão é em que condições formais e políticas a parresía cínica é praticada? Se até então havia uma politeía que garantia o direito de dizer a verdade, se até então as posses materiais, a

\footnotetext{
${ }^{7}$ Pierre Hadot se coloca a refletir com razão se o conceito de "escola filosófica" pode ser aplicado aos cínicos ou se de fato era só um modo de vida disperso. O autor defende que o discurso filosófico era ínfimo, devido ao aspecto público das pregações cínicas. Contudo, o autor sustenta que sempre houve uma relação de mestres e discípulos, e ainda mais, as ações e discursos do filósofo cínico refletem sobre o modo de vida - típica da vida de discipulado - mas por ser uma prática e um discurso público oferecem um conteúdo ético-político a todos que estiverem exposto a ele: "Et, dans toute l'Antiquité, on s'est accordé à considérer le cynisme comme une philosophie, mais comme une philosophie dans laquelle le discours philosophique était réduit au minimum. La philosophie cynique est uniquement un choix de vie, le choix de la liberté, ou de la totale indépendance (autarkeia) à l'égard des besoins inutiles, le refus du luxe et de la vanité (tuphos). Ce choix implique d'une manière évidente une certaine conception de la vie, mais celle-ci, probablement définie dans les entretiens entre maître et disciple ou dans les discours publics, n'est jamais justifiée directement dans des traités philosophiques théoriques. (HADOT, 1995, p. 172).
} 
diferenciação ética no interior da comunidade política e o status ofereciam as condições de possibilidade para a prática parresiasta, no momento cínico da parresía constata-se exatamente a ausência desses elementos materiais e formais que garantiam o espaço para o dizer verdadeiro. Luis Navia, que elege doze proposições que caracterizam o cinismo, vai destacar na décima proposição o elemento da autárkeia, como já foi destacado nas descrições de Pierre Hadot nas notas anteriores. Trata-se muito mais de uma proposição que se origina no modo de vida e conduz o cínico a ser autossuficiente. A autossuficiência coloca o cínico a parte de tudo, como destacou Foucault, e parece retirar obrigações patrióticas e dos costumes sociais. O significado da autárkeia segundo Navia (2009, p. 174). tem como consequência:

\begin{abstract}
Nem responsabilidades cívicas, nem dever de obedecer às leis, nem obrigação de respeitar e seguir normas e convenções alheias, nem a necessidade de pertencer à comunidade, nem, de fato, qualquer um dos laços costumeiros que vinculam as pessoas a seu contexto social têm valor algum ou relevância para o cínico. Vivendo entre as pessoas, ele não é uma delas e, estando no mundo, não é parte dele, uma vez que proclama ter se tornado autossuficiente.
\end{abstract}

Por isso é preciso refletir sobre a relação política que o cinismo mantém com o Estado e qual o seu legado para a posteridade. A busca da autossuficiência em relação ao Estado (autárkeia), quiçá, seja uma dessas posteridades cínicas que é preciso ter em mira. O esforço para criar um modo de vida sem nada de próprio e autossuficiente só se justifica se houver como meta a liberdade. Este tema pode ser discutido a partir da fórmula "viver de acordo com a natureza" da qual depreende-se a autarkeia ou a parresía que assumem graus de importância diferentes e são hierarquicamente distintos no movimento cínico. Branham (2007) conclui que a parresía é um dever e a autarkeia é um desejo a ser perseguido: "O valor cínico central não poderia ser nem a 'auto-suficiência' (autarkeia) - ninguém é mais dependente do que um mendigo -, nem a natureza como um princípio racionalmente formulável, equivalente à razão, como ela é no estoicismo, mas a liberdade, e a liberdade de fala (parrhésia) em particular' (BRANHAM, 2007, p. 111). Esta passagem é importante e concordamos com ela por superar uma leitura com tendências a 'estoicizar' o movimento cínico, como o faz Diógenes Laércio, por exemplo.

Trata-se muito mais de um movimento de "liberdade para" que como ideal a ser perseguido sugere formas de resistência e transformação da ordem política e social do que uma "liberdade de" como se o cínico estivesse ao lado dessas instituições e não fosse afetado por elas. O debate entre "liberdade para", e "liberdade de" foi colocado por Isaiah Berlin e 
traduz o que este autor chama de liberdade negativa (liberdade para) e liberdade positiva (liberdade de). Para sustentar a hipótese de que o cinismo representa a procura pela liberdade em seu sentido negativo, isto é, "liberdade para" nos reportamos à introdução do debate por Berlin quando em conferência em 1958 em Oxford definiu com seus ouvintes como iria usar os conceitos:

\begin{abstract}
Proponho-me examinar apenas dois destes sentidos [...] O primeiro desses sentidos políticos de liberdade individual ou liberdade institucional (farei uso de ambas as expressões para dizer a mesma coisa, o qual (com base em muitos precedentes) chamarei de sentido "negativo", vem incorporado na resposta à pergunta "Qual é a área em que o sujeito - uma pessoal ou um grupo de pessoas - deve ter ou receber para fazer o que pode fazer, ou ser o que pode ser, sem que outras pessoas interfiram?" O segundo, que chamarei de sentido positivo, vem incorporado na resposta à pergunta "O que ou quem é a fonte de controle ou de interferência que pode determinar que alguém faça ou seja tal coisa e não outra? (BERLIN, 1981, p. 136).
\end{abstract}

A passagem representa o ideal da autossuficiência e da autárkeia trazido por Navia e que a citação anterior traduz bastante. Porém, poderíamos fazer uma crítica a Berlin, pois em ambos os casos, o filósofo parece considerar o sujeito livre, como um ideal metafísico, como se se tratasse de um sujeito a-histórico que não tem como referência o próprio modo de viver. Cadahia percebe uma diferença e uma superação entre o modo como Berlin concebe a liberdade e a maneira como Michel Foucault a compreende. Para a autora, em Foucault a liberdade é sempre uma relação que o sujeito mantém com a própria história, que nos jogos políticos pode ser pensada de outra maneira.

\begin{abstract}
Aquí parece ponerse en cuestión el aspecto básico de la noción de libertad, esto es, su dimensión negativa. Si de lo que se trata es de ver cómo Foucault rompe con esta concepción, la teoría clásica de la libertad definida por Isaiah Berlin se vuelve una referencia obligada. Para éste la libertad era comprendida en sentido negativo y positivo. Mientras en el primer caso se define como una ausencia de interferencia, en el segundo se alude al derecho de realización sin intervención de una voluntad ajena al propio sujeto [...] Por 1 contrario, Foucault plantea una idea afirmativa y relacional de libertad. Más próxima al término griego eleuthería, su concepción está vinculada a una apertura, en los términos de una posibilidad de transformación del sujeto. Esta transformación no funciona a la manera de una voluntad individual que se realiza en la medida de que nada la determina, sino más bien como una potencia del pensar que emerge "de la relación que el sujeto mantiene consu propia historia (CADAHIA, 2010, p. 296-297).
\end{abstract}

Diógenes de Sinope, transfigurou a moeda no sentido de resistência e transformação dos valores vigentes e, em várias anedotas, aparece confrontando com Alexandre Magno como se não precisasse do poder do imperador para ser o que desejava ser. Tais passagens 
podem sugerir que o poder do Estado atrapalhava uma vida construída na dependência de si mesmo e da liberdade para eleger os valores que sustentavam a melhor forma de viver. Nesse sentido, o cínico é do mundo e vive com outros sem pertencer aos valores mundanos vigentes e denuncia os perigos em viver uma vida de dependência e de submissão acrítica.

Se o cínico está à frente da humanidade e está no mundo sem pertencer aos valores vigentes; se não pratica a interpretação da verdade enigmática do Oráculo; se não é um cidadão que discursa corajosamente para uma coletividade democrática de iguais; se não é um cortesão que dirige uma corajosa verdade ao soberano, então em que condições o cínico usará sua parresía? A coragem da verdade cínica não é discursiva, mas antes do discurso é o comportamento escandaloso que começa com o modo de se vestir do cínico e os objetos que porta na sua errância, como destaca Michel Foucault (2011, p. 148-149):

\footnotetext{
O cínico é o homem do cajado, é o homem da mochila, é o homem do manto, é o homem das sandálias ou dos pés descalços, é o homem da barba hirsuda, é o homem sujo. É também o homem errante, é o homem que não tem nenhuma inserção, não tem casa nem família nem lar nem pátria, é o homem da mendicidade também. [...] O modo de vida (o cajado, a mochila, a pobreza, a errância, a mendicidade) tem funções precisas em relação a essa parresía, em relação a esse dizer-a-verdade.
}

Percebe-se que a coragem da verdade cínica surge antes de qualquer ato de fala. O cajado, que denota o homem errante que usa de poucos objetos e não tem nada de próprio está vinculado a sua parresía. Trata-se da eleição de um modo de vida que sacode o modo de ser da política e da ética. A crítica cínica, de início, não se fazia por meio da palavra, mas recorria antes de tudo ao comportamento escandaloso, ou a certas atitudes que questionavam costumes coletivos, opiniões públicas consolidadas, padrões de decência, regras institucionalizadas. Muito mais que um sistema que permite o conhecimento da verdade e um discurso sobre o que é a verdade, o cinismo é um movimento histórico em que a corporeidade é o campo onde se manifesta uma verdade escandalosa, pouco ou quase nada convencional. Por estar além da dicotomia público-privado, a prática da verdade cínica está acessível a todos, configurando-se num autêntico enunciado político e ético.

Wellausen (2011, p. 126) destaca que

no cinismo a forma de vida se ramifica e aparece na história da moral ocidental como vida verdadeira: a missão do cínico é cuidar dos outros, renunciando a si, sacrificando a própria vida pela humanidade. Há um intervencionismo físico e social na forma de combate para mostrar aos homens a verdade, o princípio do bem e do mal. 
Na nossa percepção, o cinismo precisa estar inserido também na história da política ocidental e não só na história da moral. O aspecto político está presente na escrita da autora quando afirma que o cínico "sacrifica" a vida pela humanidade, que há um intervencionismo "social". Porém a ação política dos cínicos não é baixada a termo por meio de tratados, sistemas interpretativos, mas por meio do corpo que manifesta uma verdade que é também política.

\section{CONSIDERAÇÕES FINAIS}

A descrição foucaultiana do modo de vida cínica choca os padrões de felicidade que se assentam no acúmulo de posses, na ostentação de títulos acadêmicos, na estabilidade em uma comunidade específica. As condições para a ação política também são confrontadas pelo modo de ser do cínico, pois se trata de uma vida nua que não tem inserção, nem família, lar ou pátria. O legado político do cinismo revela para a atualidade que a ação política não precisa estar atrelada aos preceitos dos costumes culturais de uma coletividade, nem às formalidades do Estado que exige certas qualificações do sujeito para possuir direitos políticos plenos, mas que um modo de viver pode mostrar, “em sua nudez irredutível, as únicas coisas indispensáveis à vida humana, ou o que constitui sua essência mais elementar, mais rudimentar" (FOUCAULT, 2011, p. 160). Frédéric Gros destaca de forma bem precisa a hipótese de uma vida nua como escândalo da verdade ao tratar do tema da parresía cínica no curso de 1984: "Não se trata de regular a própria vida segundo um discurso e de ter, por exemplo, um comportamento justo defendendo a própria ideia de justiça, mas de tornar diretamente legível no corpo a presença explosiva e selvagem de uma verdade nua, de fazer da própria existência o teatro provocador do escândalo da verdade" (GROS, 2004, p. 163).

Há um legado democrático no modo de vida cínico que confronta os perigos de qualquer modelo de supremacia étnica que queira se sobressair sobre as demais, pois o cínico é sem lar e sem pátria. Disso decorre que há um conteúdo político que certamente enfrenta ideologias nacionalistas que ameaçam destruir uma comunidade política que se quer democrática, pois o cínico é o cidadão errante do mundo. Por certo o poder das hierarquias religiosas que tendem a colocar na vala da heresia as crenças menores e que também fazem parte das comunidades democráticas pode ser admoestado pela prática de vida cínica que para Foucault não tem nenhuma inserção. Quando os atenienses ouviram a Péricles, o fizeram por possuir altas capacidades cognitivas e ser o cidadão diferenciado ética e politicamente. $\mathrm{O}$ 
legado cínico sugere que há uma igualdade radical que brota do desapego do conhecimento que fundamenta hierarquias acadêmicas, que cobra dos cidadãos certos comportamentos e gestos para poder participar de uma comunidade política - o cínico é o homem da mendicância. Nessa perspectiva há um alargamento da comunidade moral e política, pois a colocação dos problemas e a busca pela solução destes não dependem dos diferenciados, mas todos estarão igualmente comprometidos com as decisões tomadas independentemente do status. É forçoso querer uma comunidade democrática assim descrita sem que os membros não tenham capacidades epistêmicas mínimas e virtudes ético-políticas simples que o cinismo e seu legado oferecem ${ }^{8}$.

\section{REFERÊNCIAS}

BERLIN, Isaiah. Quatro ensaios sobre a liberdade. Tradução Wanberto Hudson Ferreira. Brasília: Editora Universidade de Brasília, 1981.

BRANHAM, Robert Bracht. Desfigurar a moeda: a retórica de Diógenes e a invenção do cinismo. In: GOULET-CAZÉ, M.; BRANHAM, R. Brachat. Os cínicos: o movimento cínico na Antiguidade e o seu legado. Tradução Cecília Camargo Bartalotti. São Paulo: Loyola, p. 95-121, 2007

CADAHIA, Luciana. Un modo de resistir al biopoder: el lugar de la parrhesia en las reflexiones ético-políticas. Madrid, Bajo Palabra. Revista de Filosofía, no 5, p. 289-299, 2010.

DYRBERG, Torben Bech. Foucault on the Politics of Parrhesia. London: Palgrave Macmillan, 2014.

\footnotetext{
${ }^{8}$ Dyrberg se propõe a analisar em seu livro as relações entre o poder, o conhecimento e ética a para refletir sobre o tema da razão pública e da democracia e sustenta, que ao obstruir uma forte hierarquização, disciplinamento e poder biopolítico sobre as populações, é base para uma governamentalidade minimamente democrática que não pode, é claro, fugir da tríade: poder-conhecimento-ética. Por certo a parresía ao modo dos cínicos é necessária e fundamental para que essa tríade não ameace a governamentalidade democrática. "These three aspects of public political reasoning - power, knowledge and ethics - have a stabilizing elect on government, which work against fragmentation, manipulation and ill-considered decisions. They can be seen as forming governmentality, that is, political ways of governing which in varying degrees involve these three dimensions. It is important to note the temporal and spatial aspects at work here: the temporal dimension means that public political reasoning is cultivated in a political community over long stretches of time and solidly rooted in civic traditions. This makes it more dificult to establish hierarchical institutions, which thrive on a culture of dependency and subservience. It seems likely that the main target of Foucault's critical encounters is a political culture of obedience regardless of whether it is enforced by, say, sovereign, disciplinary or bio-political power. If such a culture is the flip side of elite rule, then there is a self-fulfilling prophecy involved in the latter's assumption of the political stupidity of the vast majority of the population. For the civic dignity, that goes hand in hand with a vibrant political culture, in which parrhesia is an integral part, has been wiped out in a political culture marked by conformity and collective mediocrity". (DYRBERG, 2014, p. 107).
} 
FOUCAULT, Michel. A coragem da verdade: O governo de si e dos outros. II curso dado no Collège de France (1983-1984). Tradução Eduardo Brandão. São Paulo: Martins Fontes, 2011.

FOUCAULT, Michel. O governo de si e dos outros: curso dado no Collège de France (1982-1983). Tradução Eduardo Brandão. São Paulo: Martins Fontes, 2010.

GOULET-CAZÉ, M.; BRANHAM, R. Brachat. Os cínicos: o movimento cínico na Antiguidade e o seu legado. Tradução Cecília Camargo Bartalotti. São Paulo: Loyola, 2007.

GROS, Frédéric. Foucault: a coragem da verdade. 2. ed. Tradução Marcos Marcionilo. São Paulo: Parábola, 2004.

HADOT, Pierre. Qu'est-ce que la philosophie antique ? Paris: Gallimard, 1995.

NAVIA, Luis E. Diógenes, o cínico. Tradução João Miguel Moreira Auto e Luiz Alberto Machado Cabral. São Paulo: Odysseus, 2009.

RUIZ, Castor Mari Martín Bartolomé. A filosofia como forma de vida (I): Pierre Hadot, a filosofia antiga e os exercícios de (askesis) do espírito. IHU On-Line. ${ }^{\circ}$ 461, 2015. São Leopoldo: Instituto Humanitas Unisinos, 2015, p. 10-17.

WELLAUSEN, Saly. A parrhésia em Michel Foucault: um enunciado político e ético. São Paulo: LiberArs, 2011. 